\title{
Consensus Recommendations for Advancing Breast Cancer: Risk Identifi- cation and Screening in Ethnically Diverse Younger Women
}

\author{
Alexander Stojadinovic ${ }^{1,2} \bowtie$, Thomas A Summers ${ }^{3}$, John Eberhardt ${ }^{4}$, Albert Cerussi ${ }^{5}$, Warren Grundfest ${ }^{6}$, \\ Charles M. Peterson ${ }^{7}$, Michael Brazaitis ${ }^{7}$, Elizabeth Krupinski ${ }^{8}$, Harold Freeman ${ }^{9}$
}

1. Uniformed Services University of the Health Sciences, Bethesda, MD, USA

2. United States Military Cancer Institute, Washington, D.C. , USA

3. Department of Pathology and Laboratory Services, Walter Reed Army Medical Center, Washington, DC 20307, USA

4. DecisionQ Corporation, Washington, D.C. , USA

5. University of California, Irvine, USA

6. University of California, Los Angeles, USA

7. Telemedicine and Advanced Technology Research Center, Fort Detrick, MD, USA

8. Department of Radiology, University of Arizona, Tucson, AZ, USA

9. The Ralph Lauren Center for Cancer Care and Prevention, New York, NY, USA

Corresponding author: Alexander Stojadinovic, MD FACS, Walter Reed Army Medical Center, Department of Surgery, General Surgery Service, 6900 Georgia Avenue, N.W., Washington, D.C. 20307. TEL: (202) 782-9691; FAX: (202) 782-0759; stojadinovicmd@gmail.com

(C) Ivyspring International Publisher. This is an open-access article distributed under the terms of the Creative Commons License (http://creativecommons.org/ licenses/by-nc-nd/3.0/). Reproduction is permitted for personal, noncommercial use, provided that the article is in whole, unmodified, and properly cited.

Received: 2011.03.24; Accepted: 2011.04.19; Published: 2011.04.20

\begin{abstract}
A need exists for a breast cancer risk identification paradigm that utilizes relevant demographic, clinical, and other readily obtainable patient-specific data in order to provide individualized cancer risk assessment, direct screening efforts, and detect breast cancer at an early disease stage in historically underserved populations, such as younger women (under age 40) and minority populations, who represent a disproportionate number of military beneficiaries. Recognizing this unique need for military beneficiaries, a consensus panel was convened by the USA TATRC to review available evidence for individualized breast cancer risk assessment and screening in young $(<40)$, ethnically diverse women with an overall goal of improving care for military beneficiaries. In the process of review and discussion, it was determined to publish our findings as the panel believes that our recommendations have the potential to reduce health disparities in risk assessment, health promotion, disease prevention, and early cancer detection within and in other underserved populations outside of the military. This paper aims to provide clinicians with an overview of the clinical factors, evidence and recommendations that are being used to advance risk assessment and screening for breast cancer in the military.
\end{abstract}

Key words: breast cancer, screening, personalized medicine, mammography, Bayesian Belief Networks, machine learning, Gail model, risk assessment

\section{INTRODUCTION}

The United States military serves a large number of beneficiaries with a disproportionate share of young $(<40)$, ethnically diverse women. As part of our ongoing commitment to improve the quality of care for our beneficiaries, we convened an expert panel of military and military-affiliated experts to 
review the possibility of a personalized breast cancer risk assessment paradigm relevant to young, ethnically diverse women that is based on readily obtainable clinical measures. This has yet to be developed and represents an important need in the battle to identify breast cancer early. Given the proportion of young and minority women in our nation's armed services, addressing this need is considered a priority. The development of such a screening paradigm, if proven efficacious, could have an unprecedented impact on breast cancer outcomes in our servicewomen; both by detecting already present cancers in young women, as well as raising awareness of and compliance with, annual screening mammography after age 40. This consensus report of our panel reviews current evidence for the development of such a screening paradigm in the context of existing screening approaches, along with potential means by which one could be achieved.

Breast cancer is the most common non-skin-related epithelial cancer, and second leading cause of cancer mortality among women [1]. There were over 60,000 in situ and nearly 200,000 invasive breast cancers diagnosed in the United States in 2009, and approximately 40,000 deaths from breast cancer. [3] Both incidence and mortality related to breast cancer increase with age, making it the most significant predisposing risk factor for the development of this malignancy [2]. Although the absolute risk of breast cancer in women under the age of 40 is low ( 1.1 - 3.0/1,000 women; Table 1), over 25,000 young women under 45 years old are diagnosed with breast cancer each year, and this disease remains the leading cause of cancer-related death in women aged 15-34 years $[3,4,5]$. During the early 1980s incidence rates of breast cancer increased in women under age 50, and have remained fairly stable in women in this age group since the mid-1980s. However, the incidence of disease in women under age 40 is increasing and may be underestimated $[3,6]$. Every year, over 10,000 new breast cancer cases are detected in women under the age of 40 . Over $90 \%$ of these occur among women aged $30-39$ years and on average 7.5 per every 10,000 in this age group die as a result of breast cancer every year (about 1,200 deaths annually) [3].

For women less than age 45, African American women are more likely to be diagnosed with breast cancer than are other ethnic groups. This is also true of young women in active military service, where the prevalence of breast cancer in African American women exceeds that of all other race/ethnic groups for each age category under 40 (Table 2). After age 45 white women have a higher prevalence of breast cancer [3]. Among women between the ages of 30-39, $27 \%$ of white women versus $40 \%$ African American women are diagnosed with Stage II or higher disease [3]. African American women are diagnosed at later stages of disease; hence, with more invasive cancers exceeding $5 \mathrm{~cm}$ in size, with regional nodal metastases, and with disease dissemination to distant sites [3, 16]. Although white women have higher incidence rates after age 45, African American women are more likely to die of disease at every age. For women 30-39 years, African American women are almost twice more likely to die than are white women (6.6 versus 12.8 per 10,000 women) $[3,16]$.

Table I: Prevalence of breast cancer in women under age 40 in US cancer screening studies

\begin{tabular}{|c|c|c|c|c|c|}
\hline $\begin{array}{l}\text { Number of } \\
\text { patients }\end{array}$ & $\begin{array}{l}\text { Number of } \\
\text { breast cancers }\end{array}$ & $\begin{array}{l}\text { Prevalence per } \\
1,000 \text { women }\end{array}$ & $\begin{array}{l}\text { Sensitivity of } \\
\text { Mammography }\end{array}$ & $\begin{array}{l}\text { Mammography detected } \\
\text { prevalence (can- } \\
\text { cers } / 1,000 \text { women) }\end{array}$ & Reference \\
\hline 4,402 & 5 & 1.1 & 0.82 & 0.9 & Destouet \& Sherman, 1997 [33] \\
\hline 7,308 & 22 & 3.0 & 0.77 & 2.3 & Kerlikowski et al. 1996 [34] \\
\hline 43,906 & 78 & 1.8 & 0.68 & 1.2 & Kerlikowski et al. 2000 [35] \\
\hline 11,128 & 162 & 1.5 & 0.85 & 1.2 & Bobo et al. 2000 [36] \\
\hline
\end{tabular}

Table 2: Incidence of breast cancer in active duty military women, 2000-2009

\begin{tabular}{|c|c|c|c|c|c|c|c|}
\hline \multirow[t]{2}{*}{ Race/ Ethnicity } & \multicolumn{5}{|c|}{ Incidence of breast cancer $/ 1,000$ female person years age category (years) } & & \multirow[t]{2}{*}{ Total } \\
\hline & $<20$ & $20-24$ & $25-29$ & $30-34$ & $35-39$ & $>=40$ & \\
\hline White & 0.09 & 0.16 & 0.20 & 0.65 & 1.32 & 3.24 & 0.61 \\
\hline Black & 0.17 & 0.23 & 0.33 & 0.91 & 1.34 & 3.15 & 0.77 \\
\hline Other & 0.07 & 0.17 & 0.23 & 0.59 & 1.19 & 2.51 & 0.46 \\
\hline Total & 0.11 & 0.18 & 0.24 & 0.73 & 1.31 & 3.14 & 0.64 \\
\hline
\end{tabular}

Search elements: all ages, race/ethnicity, military rank and service with primary (first occurrence) breast cancer diagnosed in the ambulatory setting: time period 2000-2009

Based on a total population 2.02 million (1.1 White, 0.61 Black, 0.29 other race/ethnicity in millions)

Source: 2000-2009 Defense Medical Epidemiologic Database, Accessed 25 Nov 2010 at http://www.afhsc.mil/aboutDmed 
It is for these reasons that a an expert panel was convened by TATRC to discuss: (1) disease prevention (e.g., through weight gain and obesity avoidance, regular physical activity, minimized alcohol consumption and exogenous hormone use, chemoprevention in at-risk women); (2) improved breast cancer early risk stratification recognizing ethnic disparities in breast cancer; and, (3) earlier disease detection in women under 40 . The principal benefits of breast cancer screening are down-staging of cancers (earlier diagnosis) and reduction of cause-specific mortality through early intervention. Down-staging impacts "incremental cost" through reduction in cancer treatment-related costs, while cause-specific mortality impacts "incremental effectiveness" through increased life years. Screening effectiveness is measured by the number of life years saved as a result of screening for breast cancer. Reduction in death due to screening is estimated to be $27 \%$ for those $50-59$ years, $20 \%$ for those $40-49$ years and $16 \%$ for those $30-39$ years [17-23]. The average life years saved by screening for women 30-39 years is 53 compared to 182 and 396 for women 40-49 years and 50-59 years, respectively, based on a cohort of 10,000 women in each group. African American women of all ages have a greater number of life years saved by screening compared to their white counterparts. It is therefore very likely that breast cancer screening will be more cost-effective for African American women compared to white women at any age.

Due to the inherent limitations of mammography in younger women, current screening guidelines do not recommend routine mammographic screening for average-risk women before the age of 40 . Consequently, the incidence of breast cancer in younger women is probably underestimated, as many cancers developing among women in their fourth decade of life (age 30-39) are not discovered until the first screening mammogram is performed, typically around age 40 . The relatively increased cancer detection rate with the first mammogram, as compared to all subsequent mammograms, supports this hypothesis [6].

The early detection of breast cancer in young women is particularly important because the disease biology is more aggressive in younger than older women [6, 7-10]. Aggressive cancers have a faster growth rate and may present in the interval between scheduled screening examinations. Breast cancer in young women demonstrates aggressive tumor biology evident in rapid tumor growth and a relatively short pre-clinical disease phase. Given that more effective treatment strategies have been developed for breast cancer in younger women, screening could favorably impact disease-related survival in younger women if it were conducted at shorter intervals than in older women [11-15]. A recent study of over 240,000 women from the SEER database, who were diagnosed with breast cancer between 1988 and 2003, found that breast cancer-specific mortality was significantly higher among younger women (age $<40$ versus $\geq 40$ years) [8]. Similar to previous reports, younger women were more likely to present with advanced stage disease (given the lack of screening) and had distinctly different tumor biology: high primary tumor grade and large size, estrogen and progesterone receptor negative, regional node positive [8]. These findings are consistent with higher mortality and a seemingly different disease etiology in younger women.

The economic burden of delayed diagnosis of breast cancer, particularly in younger women, is enormous. There are approximately 20 million women between the ages of 30-39 in the U.S. Given a breast cancer incidence of 1.5/1000 women, 30,000 cancers can be expected in this age group, most of which will not be diagnosed until annual screening mammography commences in the fifth decade of life. Many of these women in their 30s and 40s are an important part of the work force. Hence, the economic costs, as well as the emotional cost to families with children, are certainly greater when a 35-year old woman dies than when a 70-year old woman dies as a result of breast cancer. The potential benefits of risk identification, targeted screening and early cancer detection in those under 40 are correspondingly more substantial. A need exists for a breast cancer screening paradigm that can be used along with relevant demographic, clinical and other readily obtainable patient-specific data to provide individualized cancer risk assessment, direct screening efforts, and detect breast cancer at an early stage in younger women.

Given the age and ethnic composition of women in the military, addressing challenges of risk identification and screening in younger, ethnically diverse women is a particularly pressing issue in providing care to our military beneficiaries. It was with this challenge in mind that the TATRC expert panel sought to identify the current art, issues, and some potential solutions with respect to our beneficiary population.

\section{EVIDENCE - BASED MEDICINE}

Evidence-based medicine assimilates the best available clinical evidence stemming from systematic research and individual clinical expertise with the 
"conscientious, explicit and judicious use of current best evidence in making decisions about the care of patients" [26]. Levels of evidence extending from bench research to randomized clinical trials and systematic reviews/meta-analyses enable the physician to evaluate available evidence critically related to a particular problem (Figure 1) and formulate the fundamental basis of clinical decision making for the individual patient. However, other factors must be considered in the course of an individualized clinical decision, such as patient ethnicity, socioeconomic status, risk factors, educational experience, psychosocial issues, and co-morbidities. Ideally, the best level of evidence should be considered for a particular clinical problem. However, the reality is that the best level of evidence (randomized clinical trials and systematic reviews/meta-analyses) is not always available and all pertinent levels of evidence must be considered as part of clinical decision making. These decisions should also take into account clinical pathways/algorithms and guidelines stemming from multi-disciplinary consensus conferences, governmental agencies, academic and other specialty-based professional organizations (Table 3).

Schuster, McGlynn, and Brook conducted a systematic review of healthcare within the United States and found significant disparities in quality of care. In this study, up to $40 \%$ of patients were not being treated according to evidence-based best practices, $50 \%$ were not receiving recommended preventive care, and $20-30 \%$ were receiving care that is contraindicated (inappropriate, unnecessary or potentially dangerous) [27]. This study highlights the significant gap between published evidence and clinical practice. Moreover, it demonstrates the formidable barriers to implementation of evidence informed health promotion, disease prevention and treatment guidelines. A need exists for an evidence informed breast health promotion, disease prevention and breast cancer risk identification and early detection paradigm that can effectively leverage relevant, readily obtainable clinical data from the electronic health records.

Recognizing this need a consensus panel of experts was convened to provide clinicians with the clinical factors, evidence, and recommendations that will advance risk assessment and screening for breast cancer, especially for younger women (under age 40) and underserved minority populations, and to suggest future directions for research in this area. In arriving at the practical and clinically relevant recommendations contained within this document, the panel sought to maintain the highest level of evidence available with emphasis on personalized breast cancer risk assessment and screening.

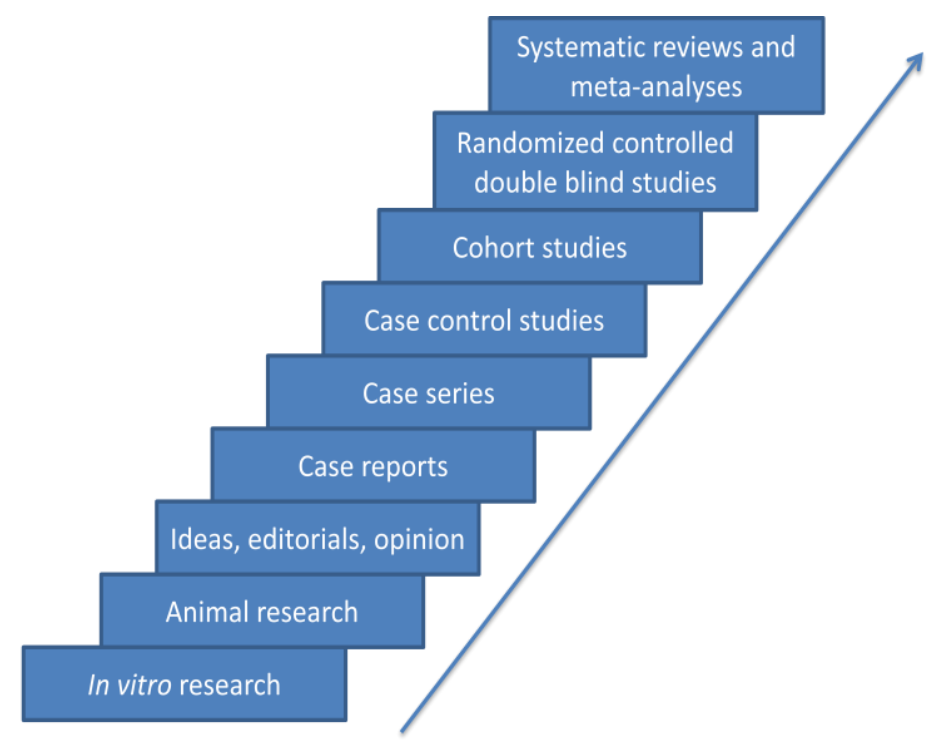

Adapted from Sackett DL, Rosenberg WM, Gray JA, Haynes RB, Richardson WA.

Evidence based medicine: What it is and what is isn't. BMJ 1996; 312 (7023): 71-2.

Figure I: Evidence-based medicine, levels of evidence 
Table 3: Guidelines and resources for breast cancer risk identification and screening

\begin{tabular}{ll}
\hline American Cancer Society (Breast Cancer Facts \& Figures) & http://www.cancer.org/research/cancerfactsfigures \\
Susan G. Komen Breast Cancer Foundation & http://ww5.komen.org/ \\
AVON Foundation for Women & http://www.avonfoundation.org/ \\
National Cancer Institute: Breast Cancer Risk Assessment Tool & http://www.cancer.gov/bcrisktool/ \\
Breast Cancer Research Foundation & www.bcrfcure.org \\
Ralph Lauren Center for Cancer Care and Prevention & http://www.ralphlaurencenter.org/ \\
Breast Cancer.org & http://www.breastcancer.org/ \\
National Breast Cancer Foundation & http://www.nationalbreastcancer.org/ \\
\hline
\end{tabular}

\section{BREAST CANCER SCREENING IN YOUNG WOMEN UNDER AGE 40}

Annual screening mammography is not recommended for average risk women under 40 because: (1) the prevalence of breast cancer in women $<40$ is lower than in older women; (2) of concerns related to repeated exposure to low dose ionizing radiation; (3) breast tissue density differs significantly in pre- versus post-menopausal women such that the sensitivity for cancer detection with screening mammography is $10-15 \%$ lower in pre-menopausal women with typically dense breast tissue; (4) the expense of following up the large number of false positive mammograms due to dense breast tissue confounds; (5) it is not considered cost effective, in view of societal costs of performing mammograms on a large patient population with relatively low overall disease prevalence; and (6) its effectiveness in decreasing breast cancer mortality in this population has not been demonstrated.

The lower sensitivity of screening mammography for dense breasts impacts age groups in which a "life saved" often results in "higher" personal and societal costs in terms of altered life expectancy and personal productivity [61]. New technologies for breast cancer screening and early detection such as magnetic resonance imaging have emerged and are recommended for women with a lifetime risk of breast cancer $>20 \%$ relative to on population-based norms. Breast MRI is unaffected by breast density, has higher sensitivity than screening mammography and increases early detection of breast cancer in high-risk young women [38, 62]. Only for this high risk population is the beneficial yield of breast cancer detection considered to be sufficiently high to offset the clinical and financial costs associated with mammography or MRI. However, as current risk assessment tools are limited in women $<40$, robust methods for screening young women are needed to identify individual women at high-risk of disease that should be consid- ered for image-based assessment of the breast and counseling for risk reducing intervention.

The current screening practice for breast cancer in average risk young women under 40 is CBE (Clinical Breast Examination) alone, which is ideally performed in conjunction with monthly breast self-examination (BSE). However, CBE is not considered clinically useful, as it: (1) is not a purely objective assessment; (2) is difficult to standardize, document and compare from year to year; (3) has very limited sensitivity for small cancers (as low as 10-17\%); and, (4) has not been shown to reduce breast cancer mortality in young women $[37,38]$. Because the CBE has low diagnostic sensitivity for small lesions, most breast cancers discovered in this manner have been growing for approximately six years [39]. Additionally, the finding that nearly $80 \%$ of breast cancers in women under age 40 are self-detected after the tumor is large enough to be palpable, supports the finding that this method of screening is suboptimal [28].

Only a few clinical trials have addressed the risks and benefits of screening CBE as a method to reduce disease-specific mortality. Of the three clinical trials conducted in third world countries with limited availability of population-based mammographic screening, one conducted in the Philippines comparing CBE to usual local practice (no formal screening) was inconclusive due to poor patient compliance and community support; the randomized trials in Cairo and India to determine the efficacy of CBE are still ongoing [40-42].

Following an initial pilot study of 5,000 women aged 35-64, the Cairo Breast Cancer Screening Trial was initiated as a block randomized controlled clinical study of 10,000 women at the Italian Hospital in Cairo, Egypt for women recruited by trained social workers [41]. Study subjects undergo either BSE and CBE $x 1$ versus BSE and CBE $x 2$ in a primary health clinic. The CBEs are performed by trained female physicians and subjects receive BSE education. This study is on-going and evaluates breast cancer inci- 
dence and diagnostic intervention with more frequent BSE/CBE screening.

A large population-based cluster randomized controlled trial was initiated in Mumbai, India in 1998, which compares health education alone provided by female health workers versus health education, BSE and CBE conducted every 2 years for underprivileged women aged 35-64 $(\mathrm{N}>150,000)$ in 20 residential areas (slums) [42]. Women in the intervention group receive four rounds of screening including visual cervical inspection for cervical cancer and 8 years of surveillance. The primary outcome variable for this on-going study is breast cancer mortality.

The applicability of these aforementioned trials to women in the United States is questionable given the distinctions between the limited healthcare resources and restricted access to mammography in Third world study settings. Although recommendations regarding screening CBE in women under 40 are conflicting [ranging from recommendations of $\mathrm{CBE}$ every 3 years for women in 20s and 30s (ACS) to CBE not recommended for women of any age (WHO) (Table 4), there is insufficient evidence to recommend for or against screening CBE in women $<40$ [37, 40-42]; (Table 5).

Two large randomized controlled clinical trials were conducted, (one in Shanghai, the other in Saint
Petersburg), along with three subsequent meta-analyses, which included these two trials and non-randomized cohort and case-control studies [43-47]. The Shanghai trial showed equivalent breast cancer mortality in both study groups and the Saint Petersburg trial found that although the rate of breast cancer detection was higher in women screened with BSE, no difference in all-cause mortality was evident between the BSE and control groups (Table 6). The data from these studies and meta-analyses do not demonstrate a benefit for BSE in terms of breast cancer survival, but the Shanghai and Saint Petersburg studies did show increased rates of breast biopsy in women undergoing BSE [43-47].

As for clinical breast examination, recommendations for BSE-based screening too are inconsistent. These guidelines vary from "BSE is optional for women starting in their 20s" (ACS), encouraging physicians to educate their patients in breast cancer detection and the technique of BSE (AMA; ACOG, $\mathrm{NCCN}$ ), insufficient evidence to recommend for or against BSE (AAFP, NCI), to recommendation against teaching BSE (USPSTF). The USPSTF recommendation against teaching BSE seems justified based on the lack of published data supporting net benefit of BSE in reducing breast cancer mortality [37]; (Table 4).

Table 4: Guidelines for the early detection of breast cancer in average risk women under age 40

\begin{tabular}{|c|c|c|}
\hline Screening method & Frequency & Reference \\
\hline \multirow[t]{5}{*}{$\begin{array}{l}\text { Breast } \\
\text { self-examination } \\
\text { (BSE) }\end{array}$} & Recommended & $\begin{array}{l}\text { American College of Obstetricians and Gynecol- } \\
\text { ogists (ACOG); American Medical Association } \\
\text { (AMA); National Comprehensive Cancer Net- } \\
\text { work (NCCN) }\end{array}$ \\
\hline & $\begin{array}{l}\text { The AMA encourages physicians to educate their patients in } \\
\text { the process of breast cancer detection, emphasizing the tech- } \\
\text { nique of self-examination of their breasts. }\end{array}$ & $\begin{array}{l}\text { American Medical Association (AMA) Policies on } \\
\text { Breast Cancer }\end{array}$ \\
\hline & Optional for women starting in their 20s & $\begin{array}{l}\text { American Cancer Society (ACS) guidelines for the } \\
\text { early detection of breast cancer }\end{array}$ \\
\hline & Insufficient evidence & $\begin{array}{l}\text { American Academy of Family Physicians (AAFP); } \\
\text { National Cancer Institute (NCI) }\end{array}$ \\
\hline & $\begin{array}{l}\text { Not recommended: The USPSTF recommends against teaching } \\
\text { BSE. There is moderate or high certainty that the service has no } \\
\text { net benefit or that the harms outweigh the benefits. }\end{array}$ & U.S. Preventive Services Task Force (USPSTF) \\
\hline \multirow[t]{4}{*}{$\begin{array}{l}\text { Clinical breast ex- } \\
\text { amination (CBE) }\end{array}$} & $\begin{array}{l}\text { Recommended every three years for women in their } 20 \text { s and } \\
30 \text { s }\end{array}$ & $\begin{array}{l}\text { American Cancer Society guidelines for the early } \\
\text { detection of breast cancer }\end{array}$ \\
\hline & Recommended annually for women age $40+$ & ACOG, NCCN, ACS \\
\hline & $\begin{array}{l}\text { Insufficient evidence: No USPSTF recommendation for women } \\
<40 ; \text { however the USPSTF concludes that evidence is lacking } \\
\text { and the balance of harms and benefits cannot be determined } \\
\text { for CBE as a supplement to mammography in older women. }\end{array}$ & U.S. Preventive Services Task Force \\
\hline & Not recommended for women of any age & World Health Organization \\
\hline
\end{tabular}


Table 5: Clinical Breast Examination clinical trials

\begin{tabular}{|c|c|c|c|c|c|c|}
\hline $\begin{array}{l}\text { Age } \\
\text { group } \\
\text { (years) }\end{array}$ & Study years & Design and Setting & Protocol & $\begin{array}{l}\text { Primary out- } \\
\text { come }\end{array}$ & $\begin{array}{l}\text { Secondary out- } \\
\text { come }\end{array}$ & Result and reference \\
\hline $35-64$ & $\begin{array}{l}1996-1997 \\
\text { first round } \\
\text { screening }\end{array}$ & $\begin{array}{l}\text { RCT; block ran- } \\
\text { domization; } \\
\text { Manila, Philippines; } \\
202 \text { health centers in } \\
12 \text { municipalities }\end{array}$ & $\begin{array}{l}\text { MAMMACARE in- } \\
\text { struction; Annual CBE } \\
\text { x } 5 \text { versus } \\
\text { nurse/midwife usual } \\
\text { practice }\end{array}$ & $\begin{array}{l}\text { No breast } \\
\text { cancer mor- } \\
\text { tality report- } \\
\text { ed }\end{array}$ & $\begin{array}{l}\text { Relative risk not } \\
\text { calculated due to } \\
\text { limited }(35 \%) \\
\text { diagnostic test- } \\
\text { ing after positive } \\
\text { CBE }\end{array}$ & $\begin{array}{l}\text { Inconclusive; low overall } \\
\text { study participation } \\
\text { " refractory attitude" } \\
\text { amongst study subjects) } \\
\text { with frequent drop outs } \\
\text { after } 1 \text { st round of } \\
\text { screening; Sensitivi- } \\
\text { ty=26\% and Positive } \\
\text { Predictive Value=1\% of } \\
\text { screening program; } \\
\text { Screen detected cases } \\
\text { were not more advanced } \\
\text { than others [40] }\end{array}$ \\
\hline $39-65$ & $\begin{array}{l}\text { 2000-2002 } \\
\text { (Pilot); } \\
\text { RCT enrolling }\end{array}$ & $\begin{array}{l}\text { RCT; block ran- } \\
\text { domization; } \\
\text { Italian Hospital } \\
\text { region, Cairo, Egypt }\end{array}$ & $\begin{array}{l}\text { CBE training locally } 2 \\
\text { months before trial; } \\
\text { CBE/BSE x } 2 \text { versus } \\
\text { CBE/SBE x1 by fe- } \\
\text { male physician }\end{array}$ & $\begin{array}{l}\text { Breast cancer } \\
\text { incidence }\end{array}$ & $\begin{array}{l}\text { Benign biopsies: } \\
1.2 \% \text { after 1st } \\
\text { round }\end{array}$ & $\begin{array}{l}\text { High rate of } 1 \text { st and } 2 \text { nd } \\
\text { round breast cancer } \\
\text { detection rate: } 8 / 1,000 \\
\text { and } 2 / 1,000 ; \text { Study in } \\
\text { progress [41] }\end{array}$ \\
\hline $35-64$ & $\begin{array}{l}1998 \text {-; } \\
\text { RCT enrolling }\end{array}$ & $\begin{array}{l}\text { RCT; cluster ran- } \\
\text { domization; } \\
\text { Mumbai, India }\end{array}$ & $\begin{array}{l}\mathrm{CBE} \text { training } \times 5 \\
\text { months before trial; } \\
\mathrm{CBE} / \mathrm{BSE} / \text { Breast } \\
\text { health education eve- } \\
\text { ry } 24 \text { months } \times 4 \\
\text { versus education alone } \\
\text { delivered by well } \\
\text { woman health work- } \\
\text { ers }\end{array}$ & $\begin{array}{l}\text { Breast cancer } \\
\text { mortality }\end{array}$ & Not available & Study in progress [42] \\
\hline
\end{tabular}

Table 6: Breast Self-Examination clinical trials

\begin{tabular}{|c|c|c|c|c|c|c|}
\hline $\begin{array}{l}\text { Age } \\
\text { group } \\
\text { (years) }\end{array}$ & $\begin{array}{l}\text { Study } \\
\text { years }\end{array}$ & $\begin{array}{l}\text { Design } \\
\text { Setting }\end{array}$ & Protocol & $\begin{array}{l}\text { Primary } \\
\text { outcome }\end{array}$ & $\begin{array}{l}\text { Secondary out- } \\
\text { come }\end{array}$ & Result and reference \\
\hline $31-65$ & 1989-2000 & $\begin{array}{l}\text { RCT: Shanghai, } \\
\text { China; women } \\
\text { working in } \\
\text { factories }\end{array}$ & $\begin{array}{l}\text { Instruction on breast anatomy } \\
\text { and } 3 \text {-step BSE by trained } \\
\text { factory medical worker with } \\
\text { instruction reinforcement at } 1 \\
\text { and } 3 \text { years and medically } \\
\text { supervised CBE every } 6 \\
\text { months (women practiced } \\
\text { supervised BSE } 1,3,6 \text {, and } 9 \\
\text { months after initial instruction } \\
\text { during year } 1 \text { and every } 6 \\
\text { months for next } 4 \text { years). } \\
\text { versus } \\
\text { No information on breast } \\
\text { cancer screening }\end{array}$ & $\begin{array}{l}\text { Relative Risk } \\
\text { (RR) for } \\
\text { breast cancer } \\
\text { mortality }= \\
1.03 \\
(95 \% \text { CI, } \\
0.81-1.31)\end{array}$ & $\begin{array}{l}\text { Benign biop- } \\
\text { sies: } \\
\text { RR = } 1.57 \\
(95 \% \text { CI, } \\
1.48-1.68)\end{array}$ & $\begin{array}{l}\text { Breast cancer was } \\
6.5 / 1,000 \text { women in the } \\
\text { BSE group and } 6.7 / 1,000 \\
\text { in control group. Breast } \\
\text { cancer mortality equiva- } \\
\text { lent in both groups [43]. }\end{array}$ \\
\hline $40-64$ & 1985-2001 & $\begin{array}{l}\mathrm{RCT} \text {, cluster } \\
\text { randomization; } \\
\text { Saint Peters- } \\
\text { burg, Russia; } \\
\text { women at- } \\
\text { tending clinics; } \\
\mathrm{n}=123,748\end{array}$ & $\begin{array}{l}\text { Nurses or providers receive } \\
\text { 3-hour training on BSE prior to } \\
\text { instructing groups of } 5-20 \\
\text { women. BSE instruction } \\
\text { with reinforcement every } 3 \\
\text { years provided by the trained } \\
\text { personnel [CBE with review of } \\
\text { BSE at annual clinic visits] } \\
\text { versus } \\
\text { no instruction; }\end{array}$ & $\begin{array}{l}\text { Relative Risk } \\
\text { (RR) for all } \\
\text { cause mor- } \\
\text { tality = } \\
1.07 \\
(95 \% \text { CI, } \\
0.88-1.29) \\
\\
\text { Breast cancer } \\
\text { mortality not } \\
\text { reported. }\end{array}$ & $\begin{array}{l}\text { Benign biop- } \\
\text { sies: RR } 2.05 \\
(95 \% \text { CI, } \\
1.80-2.33)\end{array}$ & $\begin{array}{l}\text { Only } 18 \% \text { reported per- } \\
\text { forming monthly BSE } \\
\text { within } 4 \text { years of enroll- } \\
\text { ment, which prompted } \\
\text { BSE refresher every } 3 \\
\text { years. Even with BSE } \\
\text { instruction reinforcement, } \\
\text { only } 58 \% \text { of women per- } \\
\text { formed monthly BSE. } \\
\text { Various publications from } \\
\text { this study have unex- } \\
\text { plained inconsistencies in } \\
\text { data reporting [44] }\end{array}$ \\
\hline
\end{tabular}


Breast cancer screening with CBE and BSE is not without risk; and, include adverse psychological effects such as apprehension, anxiety, and concern, as well as false negative examination. Fenton et al. assessed the accuracy of CBE in asymptomatic women in five states within the U.S. who received CBE within 1 year of breast cancer diagnosis and who died within 15 years of diagnosis [48]. Community-based CBE was found to have poor sensitivity $(21.6 \%$ : $95 \% \mathrm{CI}=$ $18.1-25.6 \%)$ for the detection of lethal breast cancer. The findings of this study suggest high false-negative rate of CBE and/or biologically virulent breast cancer occurring between screening CBEs. In studies of population-based BSE screening, the rate of benign biopsy was significantly increased in women undergoing BSE than controls (RR 1.57 in the Shanghai PRT and RR 2.05 in the Saint Petersburg PRT) [43, 44].

\section{BREAST CANCER ASSOCIATED RISK FACTORS AND IDENTIFICATION OF AT-RISK YOUNG WOMEN}

Although breast cancer risk factors are well known (e.g., increasing age, family history of the disease, early menarche, late menopause, breast density, age at first full-term pregnancy, exogenous estrogen and progestin use), only a minority of women that develop breast cancer carry a known risk factor, and only $5-10 \%$ have a documented family history of the disease or a genetic predisposition to it. Therefore, $\geq$ $90 \%$ of women who develop breast cancer do not have a known risk factor. Most breast cancers occur in women with only two non-specific disease-associated risk factors, namely age and female gender. Importantly, due to inherent limitations in clinical breast examination (CBE), nearly three-fourths of breast cancers in women $<45$ are identified on breast self examination (BSE) [28].

Table 7 shows the breast cancer-associated risk factors and lifetime relative risk of disease ranges for women with the various conditions used to recommend early screening in women under age 40. Many of the risk factors are non-modifiable - age, family history of breast and ovarian cancer, breast cancer associated gene mutations (hereditary mutations in tumor suppressor genes $B R C A 1$ and $B R C A 2)$, personal history of non-invasive breast cancer or diagnostic biopsy revealing proliferative lesions with cellular atypia or lobular carcinoma in situ (LCIS), history of radiation exposure to the thorax (e.g. high-dose man- tle radiation treatment for Hodgkin's lymphoma), extensive breast tissue density (excess glandular relative to fatty tissue apparent on mammography), early menarche, age at first full-term pregnancy, nulliparity, late menopause, and obesity relating to prolonged breast exposure to circulating ovarian hormones. The Women's Health Initiative trial demonstrated that estrogen/progestin hormone replacement therapy in post-menopausal women is associated with increased risk of breast cancer [51]. Some breast cancer risk factors (obesity, breast feeding, alcohol consumption, oral contraception use, etc.) are modifiable through health promotion and disease prevention strategies. These strategies include regular physical activity, healthy body weight management, minimizing alcohol consumption, and judicious use of post-menopausal hormones.

Statistical models (risk assessment tools) are currently in use to estimate risk of breast cancer (including but not limited to Gail Model, NCI Breast Cancer Risk Assessment Tool, Claus Model, BRACPRO, MYRIAD II, Tyrer-Cuzick Model - International Breast Cancer Intervention Study. These models take into account various disease-associated risk factors (all include age and family history of breast cancer amongst $1^{\text {st }}$ degree relatives), but indications for use vary. For example, BRACPRO is a statistical model used to guide genetic counselling in women at high risk for developing hereditary breast and ovarian cancer. The Tyrer-Cuzick model predicts risk of breast cancer based on high risk features and makes (and may over-estimate) risk adjustment based on history of atypical hyperplasia [52]. The risk estimates provided with models currently used are better suited for population-based rather than individualized risk calculation.

One of the most commonly utilized relative risk assessment tools for seemingly average-risk young women is the Gail Model. However, models such as this are imperfect [53]. Currently, the only criterion generally used to identify high-risk women under 40 who could benefit from chemoprevention is family/genetic history. The value of this screening approach is limited by the rarity of breast cancer due to known hereditary mutations in tumor suppressor genes BRCA1 and BRCA2. Better screening methods are needed to identify at-risk women $<40$ who could benefit from risk reduction via chemoprevention. 
Table 7: Lifetime relative risk of breast cancer for women with various conditions commonly used to recommend early screening before the age of 40

\begin{tabular}{|c|c|c|c|}
\hline Class & Condition & Relative risk & Reference \\
\hline \multirow[t]{3}{*}{ Family history } & One 1st degree relative & $1.7-2.0$ & $\begin{array}{l}\text { Pharoah et al., } 2000 \text { [29]; } \\
\text { Collaborative Group on } \\
\text { Hormonal Factors in Breast } \\
\text { Cancer, } 2001 \text { [30] }\end{array}$ \\
\hline & Two 1st degree relatives & 2.0 & $\begin{array}{l}\text { Collaborative Group on } \\
\text { Hormonal Factors in Breast } \\
\text { Cancer, } 2001 \text { [30] }\end{array}$ \\
\hline & Three or more 1st degree relatives & 3.9 & $\begin{array}{l}\text { Collaborative Group on } \\
\text { Hormonal Factors in Breast } \\
\text { Cancer, 2001 [30] }\end{array}$ \\
\hline Inherited genetic mutation & BRCA1 or BRCA2 & 5.7 & Schwab et al., 2002 [31] \\
\hline \multirow[t]{3}{*}{ Histology of breast biopsy } & Personal history of breast cancer & $2.0-4.0$ & Feig et al., 1998 [32] \\
\hline & Atypical Hyperplasia & 4.0 & Feig et al., 1998 [32] \\
\hline & LCIS & $5.9-12.0$ & Feig et al., 1998 [32] \\
\hline \multirow[t]{3}{*}{ Other high-risk factors } & $\begin{array}{l}\text { Female; } \\
\text { Age ( } 65+\text { vs. }<65 \text { years); } \\
\text { High breast tissue density; }\end{array}$ & $>4.0$ & $\begin{array}{l}\text { Breast Cancer Facts \& Figures } \\
2009-2010[3]\end{array}$ \\
\hline & $\begin{array}{l}\text { High-dose chest radiation; } \\
\text { High bone density post-menopausal }\end{array}$ & $2.1-4.0$ & $\begin{array}{l}\text { Breast Cancer Facts \& Figures } \\
2009-2010 \text { [3] }\end{array}$ \\
\hline & $\begin{array}{l}\text { Personal history of endometrial or ovarian } \\
\text { cancer; } \\
\text { Alcohol consumption; } \\
\text { High socioeconomic status; } \\
\text { Ashkenazi Jewish heritage }\end{array}$ & $1.1-2.0$ & $\begin{array}{l}\text { Breast Cancer Facts \& Figures } \\
2009-2010[3]\end{array}$ \\
\hline $\begin{array}{l}\text { Factors affecting circulating } \\
\text { hormones }\end{array}$ & $\begin{array}{l}\text { Age > } 30 \text { years at first full-term pregnancy; } \\
\text { Early menarche (Age }<12) ; \\
\text { Late menopause (Age >55); } \\
\text { No full-term pregnancies; } \\
\text { Never breastfed a child; } \\
\text { Recent oral contraceptive use; } \\
\text { Recent and long-term use of estrogen and } \\
\text { progestin; } \\
\text { Obesity (postmenopausal) }\end{array}$ & $1.1-2.0$ & $\begin{array}{l}\text { Breast Cancer Facts \& Figures } \\
2009-2010[3]\end{array}$ \\
\hline
\end{tabular}

\section{BREAST CANCER RISK REDUCTION THROUGH CHEMOPREVENTION}

The identification of women who are at high risk for the development of breast cancer and may benefit from chemoprevention is important. In the NSABP P-1 study, Tamoxifen reduced the incidence of breast cancer by approximately $50 \%$ in at-risk women across all study age and risk groups [54]. The NSABP P-1 study provided definitive evidence that chemoprevention is an efficacious approach for breast cancer risk reduction [54]. Subsequent analyses suggested improved quality-adjusted survival and cost effectiveness when Tamoxifen was initiated as early as age 35 in at-risk (Gail Model 5-year risk $\geq 1.66$ ) women [55, 56]. Given the rarity of breast cancer gene mutation-associated breast cancer and the imperfections of clinical risk assessment for the disease, improved individualized screening methods are imperative to identify at-risk women $<40$ who stand to benefit from risk reduction via chemoprevention.
As breast cancer in young women is associated with unfavorable biological features contributing to high cause-specific mortality, early detection is an important clinical aim [7, 8, 57]. Women under age 40 are not referred for early image-based screening unless they are identified as being "high risk", which represents less than $10 \%$ of women [58-62]. "At risk" women $<40$ with significant family history or genetic factors, are typically advised to undergo frequent clinical breast and annual screening mammography (MMG) examination and consider chemoprevention. While increased surveillance for "at risk" women appears beneficial, the value of this approach is restricted by the rarity of breast cancer due to known genetic risk factors.

\section{CONTROVERSY AND UNMET NEEDS IN BREAST CANCER SCREENING AMONG YOUNG WOMEN}

The issue of breast cancer in younger women has unique ramifications for society, particularly in rela- 
tively young, ethnically diverse female populations such as the United States military which are considered at-risk. Further, the importance of early detection of disease is increased in the military population since early stage disease can be treated in a manner which allows servicewomen to return to duty swiftly and continue to serve our country. While there is disagreement about tumor growth rates in the literature, there is general consensus that early detection of disease results in breast cancer down-staging and improved oncological outcomes. New evidence on chemoprevention and the management of breast cancer also indicates that an effective screening modality has the potential to increase survival, with resulting economic and quality of life benefits.

The current debate in breast cancer screening has been ongoing for at least 15 years and is well described. In 1997, the NCI convened a Consensus Development Conference on the subject of breast cancer screening in younger women, which failed to produce the consensus desired by many: "The $[\mathrm{NCI}]$ panel also recommended that a woman's decision about whether to undergo mammography should be based not only on the scientific evidence, but also on her medical history, her perception of risk and benefit, and how she deals with uncertainty. Indeed, while results from both meta-analyses and individual trials presented at the meeting revealed statistically significant breast cancer mortality reductions for women aged 40-49 at randomization, it appeared that the debate had shifted from the lack of statistically significant endpoints to that of risk/ benefit and cost effectiveness." [50] Thus, much of the debate centers on the risk-benefit to the patient and on the cost-effectiveness of breast cancer screening. The debate is compounded by conflicting study results as to the actual effect on mortality of breast cancer screening and early detection and new information on the harms associated with repeated exposure to ionizing radiation. With an active debate on the relative benefit of screening and early detection, a new focus on managing healthcare costs, and concerns about radiation exposure, it does not appear that the debate will be resolved anytime in the near future.

Hypothetically, the development of less invasive screening methods, lower cost screening methods, methods with a higher degree of accuracy, or all three, would have the ability to shift the focus of the debate. If the cost of screening, in terms of both dollar costs and morbidity risk, were to be substantially lowered, this would then alter the cost-benefit equation from the cost side. Further, if the accuracy and/or performance of screening technologies were improved (improved sensitivity and/or specificity), this could alter the cost-benefit equation from the benefit side.

Given our commitment to our duty of care to our young active servicewomen, the TATRC expert panel sought to evaluate technologies and approaches that have the potential to alter both the cost and benefit sides of the equation. Not only does the composition of our population necessitate making these advances to provide them the best quality of health promotion and cancer care, but the unique nature of the Military Health System as a closed-loop system provides a unique environment to develop and evaluate the potential costs and benefits of these types of technologies and approaches.

\section{GOALS IN MILITARY BREAST CANCER SCREENING AMONG YOUNG WOMEN}

The over-arching goal in breast cancer screening for young women in the military is the development of new technologies that can advance the paradigm of personalized breast cancer risk assessment and treatment. We seek to focus on parameters routinely collected as part of standard clinical practice and on the use of novel technologies that can either improve statistical performance or reduce costs. This is particularly relevant in view of recent findings suggesting that the inclusion of newly discovered genetic variants associated with breast cancer in existing risk prediction models only has a marginal improvement in overall model performance [63]. In evaluating criteria for the adoption of new technologies, the TATRC panel identified six key attributes in order to be effective in improving the current breast cancer risk identification and screening paradigm: 1 ) pervasive access; 2) relatively low cost; 3) low risk to the patient; 4) relatively high accuracy; 5) quality assessment built in by design; and, 6) prospective design that supports ongoing improvement.

Pervasive access is the need to develop technologies that can be made broadly available to as many women as possible across the spectrum of socioeconomic classes and access to care. While it is not easy to say what these technologies are, we can say what they are not. In order to be pervasive, they cannot (a) require access to capital equipment that is costly and protracts new testing, (b) require the training of new cadres of health professionals, or (c) radically alter or disrupt the current practice workflow or standard of practice. However, it is important to note that we currently lack an acceptable evidence-informed standard of practice for breast cancer risk identification and screening in young women. These technologies could include screening algorithms, novel anatomic and/or functional imaging methodologies, novel diagnostic tests, or some innovative combina- 
tion of existing imaging, testing and clinical informatics.

Relatively low cost technological innovation means that these pervasive technologies must either reduce, or minimally impact, current screening program-related costs. Ideal risk identifying and/or screening technologies could achieve this goal by providing risk stratification and screening at a significantly lower cost than current methods, or by providing higher detection rates and fewer false positives (no significant increase in breast biopsy rate) at the current cost per beneficiary. In order to improve the current paradigm, cost effectiveness must be considered concurrently with research and development.

Low risk to the patient is essential. The development of minimally or non-invasive risk identification techniques and technologies is essential in order to improve risk stratification and early detection while reducing exposure risk to the patient. An example of this imperative is the debate over mammographic screening in women under 40 . While mammography is a non-invasive, relatively low risk technology, it is not minimal risk, as regular mammographic screening exposes the beneficiary to radiation. This raises the valid concern, given low disease prevalence rates in the population, of exposing large numbers of healthy women to unnecessary radiation in order to identify one pre-clinical cancer. For example, the Age Trial enrolled nearly 161,000 women age 39-41 who were randomly assigned to annual screening mammography until age 48 versus control (standard practice in the United Kingdom), wherein a significant reduction in all-cause and breast cancer mortality was identified. However, the number needed to screen in order to prevent one breast cancer-related death over 10 years was 2,512 [64]. Further, screening in younger women should be conducted at shorter intervals in order to derive the benefits of early detection, since the pre-clinical detectable phase in young women is shorter than in older and post-menopausal women [26]. This creates a "Catch-22" under the current screening paradigm, where the clinical benefit requires a high level of exposure in a broad population for the detection of very few instances of disease. Hence, developing minimal risk methods and technologies has the potential to solve this conundrum.

Relatively high accuracy means that any new technology must, at the very least, improve the current sensitivity and/or specificity of the current risk screening paradigm. When debating cost effectiveness, it is important to remember that not only can costs be controlled, but new technology should provide clinically relevant improvement in screening efficacy, while reducing false positive events. With improved sensitivity, the cost per detection decreases and relative benefit increases. With improved specificity, the psychological and physical costs of false positives are decreased, as are the risks associated with unnecessary imaging and invasive diagnostic intervention.

Quality assessment should be built into these systems by design. The traditional paradigm for the development of clinical methods and technologies is oriented principally toward diagnostic devices - development, evaluation, study and validation. It is viewed as a finite process toward the development of a commercially viable, production ready device. However, risk identification and stratification are a process, and as a process, require ongoing evaluation and improvement in order to deliver maximum benefit to our beneficiaries. Thus, any of the technologies and methodologies developed should have processes designed for ongoing audit, review, and evaluation. An additional benefit of this ongoing evaluation would be improved post-market data for the FDA to consider when evaluating and approving newer technologies.

Prospective design to support ongoing improvement is the logical counterpart of ongoing quality assessment. Prospective design means designing technologies and methods that are intended to support continuous change and quality improvement. The process for future design improvements must be built into any new technologies at the outset to ensure the continuous improvement of accuracy, reduction of cost, and overall quality assurance. These goals can be translated into a set of criteria that can be used to measure the efficacy of novel risk identification and screening technologies and methodologies.

\section{CRITERIA FOR EFFECTIVE BREAST CANCER SCREENING AMONG YOUNG WOMEN}

Criteria for screening effectiveness should mirror goals, and can thus be described in six categories: 1 ) access metrics, 2) dollar cost, 3) risk to the patient, 4) accuracy statistics, 5) quality statistics and metrics, and 6) success of ongoing quality improvement.

As a criterion for success, access can be measured in several ways. First, what types of providers and institutions can use the technology? Does it require investment in capital equipment, sophisticated health informatics systems, or personnel? Second, are there geographic limitations to how the technology can be deployed? Third, how many beneficiaries have access to the technology? 
Cost can be measured, at a basic level, as the actual cost of the technology. However, cost needs to be considered in a complete sense, wherein the cost needs to include incremental costs of additional referrals or procedures, as well as benefits of early detection in at-risk women, or reducing unnecessary procedures for low risk beneficiaries. Further, cost should be benchmarked against other existing methods, and should be adjusted appropriately to account for either improvements or reductions in screening method sensitivity and specificity. An ideal solution should, overall, result in increased disease detection through a lower overall recall rate at reduced total cost.

Risk must be measured in order to complement cost in the cost-benefit analysis of risk identification and screening. In order to address the current debate over cost-benefit of screening, any new solution should present a lower risk level than current "solutions". The risk level to the individual patient with the novel approach should be lower or commensurate with existing technology, while substantially lowering aggregate population risk.

The measurement and evaluation of risk assessment and screening accuracy is critical. In order to be effective, novel risk evaluation and screening technologies should improve current sensitivity and specificity. This is critically inter-related with cost, risk, and benefit. Ideally, novel approaches can improve both sensitivity and specificity; however it is often the case that technology must of necessity be optimized toward one or the other parameter. We will need to consider the relative benefit of sensitivity versus specificity, a calculation which cannot be performed without also understanding overall disease prevalence, cost, risk, and the clinical benefits of early detection. Hence, the groundwork for rigorous prospective study and evaluation of all new technologies must be established in order to develop validated metrics for sensitivity and specificity.

Quality statistics and metrics require the collection of performance data on an ongoing basis. This means that data regarding cost, sensitivity, and specificity should continue to be collected even after prospective evaluation is completed. Further, data should not only be collected on accuracy, referral rates, positive and negative predictive values, and detection and recall rates, but data should also be collected on patterns of use across a broad spectrum of clinical locations and activity, the quality of user interactions with the technology and how the technology influences clinical workflow patterns. The ability to study how clinicians and patients interact with novel risk identification and screening technologies will allow us not only to improve the accuracy and quality of the screening programs, but to identify design elements that can improve the user experience and encourage proper use of the technology, with the aim of advancing clinical decision support.

Finally, we must be able to demonstrate that the criteria and metrics described above can be reincorporated into an improved set of technologies and methods, i.e., success of on-going quality improvement.

\section{FOCUS AREAS OF OPPORTUNITY TO IMPROVE BREAST CANCER SCREENING AMONG YOUNG WOMEN}

Based on our assessment of needs, goals, and criteria for success, our working group identified three promising areas of development for the next generation of breast cancer risk assessment and screening: 1) improved algorithmic screening; 2) development of novel circulating tumor cell (CTC) evaluations; and, 3) development of novel biomarkers of disease.

Improved algorithmic screening consists of the use of advanced statistical algorithms to improve the interpretation of readily available clinical, demographic, and risk factor information. There is a tremendous amount of information available through the clinical record, patient history and patient demographics; however, we have confined our efforts pursuant to risk stratification to relatively simple, limited models and algorithms. Early work indicates that enhanced risk stratification algorithms can be used to enhance referral through increased access at low cost, with improved sensitivity and specificity. We have recently demonstrated proof of concept for using clinical data from a prospective pilot breast cancer screening study of young women $(n=591)$ to train, test and cross validate a Bayesian Belief Network model (Figure 2) [65]. Initial cross-validation results are hypothesis-generating and appear promising; area under the receiver operating characteristic curve for benign and malignant biopsy outcomes was 0.88 and 0.97 , and positive predictive value was $97 \%$ and $42 \%$, respectively, suggesting that the BBN model may provide clinically useful individualized risk estimates based on data collected as part of breast cancer screening [65]. 


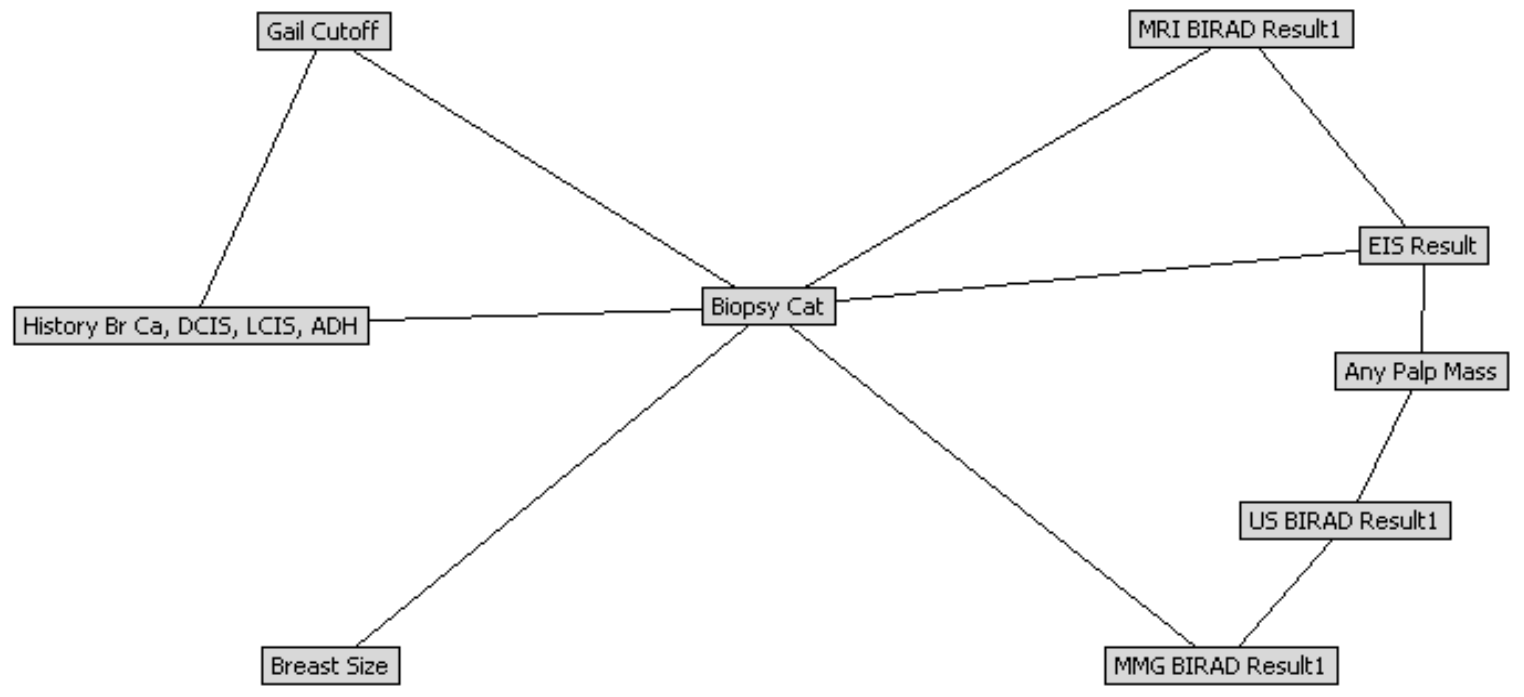

Figure 2: Bayesian Belief Network model, proof of concept for using clinical data from a prospective pilot breast cancer screening study of young women to train, test and cross validate a Bayesian classifier. Primary outcome variable is breast biopsy histopathology (benign, pre-malignant, malignant)

Novel applications of CTCs also have the promise to provide an additional tool for improving risk stratification and screening. While CTCs require specialized expertise and equipment, if used properly they could serve in a very complementary role to the development of novel algorithms and biomarkers as well as existing imaging technologies [66-72]. CTCs are cells that have detached from a primary or metastatic tumor and entered the peripheral circulation. CTCs should not be identified in patients without an epithelial malignancy [66]. Several methodologies have been developed to detect and characterize disseminated tumor cells (DTCs), as they are called in bone marrow, or CTCs in peripheral blood of cancer patients. These methodologies fall under two main categories: immunological based assays and molecular based assays. Although these approaches can be used directly, an enrichment step prior to the detection is preferred. A number of methodologies exist for enriching rare cancer cells, including density gradient separation to enrich for nucleated cells (i.e., Ficoll gradient separation), and magnetic cell separation either targeting the cancer cell, positive immunomagnetic cell separation (PIMS), or negative immunomagnetic cell separation (NIMS), where normal blood cells are targeted. Unfortunately, most of the reported studies using some form of magnetic cell separation to separate or enrich rare cancer cells do not provide data, or complete data, on the performance of the magnetic separation step. Consequently, it makes comparison of the performance of technology, as well as the overall study, difficult or impossible.

The current model of tumor biology identifies metastasis as the final step in a linear model of cancer progression. Metastases are thus believed not to occur until tumors have reached an adequately large size and acquired additional mutations that allow these mutated cells to disseminate and grow at distant sites (the 'emancipated cell'). However, current clinical, epidemiological, and experimental data refute this model [66, 73-85] and suggest that systemic spread is an early event in breast cancer, possibly occurring prior to ductal carcinoma in situ [80].

CTCs are identifiable in patients without detectable cancer and may be a potential early disease marker [86-89]. Reliable and accurate detection of these CTCs is now possible with a simple peripheral venous blood draw. A study has been initiated within the DoD, which hypothesizes that women with CTCs and no other clinically apparent signs of malignancy have clinically undetectable disease (Walter Reed Army Medical Center Department of Clinical Investigation Protocol: Circulating Tumor Cells (CTCs): A potential screening test for clinically undetectable 
breast carcinoma; PI: Thomas A. Summers). This study will attempt to validate the CTC detection technology as a breast cancer screening test and acquire data to determine the clinical validity and utility of this proposed screening methodology on a relatively young, ethnically diverse population who are eligible military health care beneficiaries. Furthermore, this study will attempt to bank identified CTCs in order to perform additional molecular analyses in the future. The study's specific aims are to develop a simple, reliable, cost-effective, and clinically relevant breast cancer screening test in order to identify subclinical disease early in its natural history in subjects at risk of progression to clinically apparent disease over the ensuing decade. The study team's ultimate goal is to decrease the treatment-related morbidity and cause-specific mortality of breast cancer.

Novel biomarkers also have dramatic potential to improve disease detection, amongst other endpoints, in the breast cancer population. Biomarkers represent any characteristic that can be objectively measured and evaluated in relation to the point of interest. Biomarkers can generally be applied to indicate disease presence, progression, or recurrence, or more specifically tailored to a clinical situation of interest (i.e. response to a specific therapy; e.g. Traztuzumab adjuvant therapy in patients with Her2/neu expressing breast cancer). A broad definition of a $b i$ omarker is any physical, functional, or biochemical indicator of a physiological or disease process that has diagnostic and/or prognostic utility [90].

The ability to study and treat breast cancer in young, ethnically diverse women is hampered by a lack of novel, reproducible, accurate, quantifiable, easily obtainable and measureable biomarkers that correlate well with the presence of breast cancer early in the time course of cancer development (i.e., prior to development of a clinically identifiable mass). As highlighted above, there is no reliable way to screen for breast cancer in its earliest stages; consequently, the clinical presentation of disease is at a stage where reversal or optimal control is diminished. Similarly, there are no generally accepted methods for monitoring disease progression or the evaluating accurately the efficacy of potential therapeutic interventions short of clinically observable signs or symptoms (e.g., reduced size and activity of a metastasis on CT-PET scan). This can make disease follow-up more of a 'wait-to-treat' practice, rather than a pro-active one. Through the use of biomarkers the potential to individualize risk assessment and diagnosis and further advance into the era of "personalized medicine" may be realized.
An explosion in biomarker discovery and research has resulted from recent advances in molecular medicine. Additionally, the advancements in molecular medicine have resulted in the development of new technologies aimed at biomarker discovery. Genomic, proteomic, and functional imaging tools have emerged, which have identified vast amounts of data concerning single nucleotide polymorphisms, microRNAs, methylation signatures, as well as genes and master control genes (homeobox genes), which might be valuable information in the form of predictive or prognostic biomarkers in breast cancer. Novel approaches in the development of in-vitro diagnostic multi-marker index assays have shown that combining multiple biomarkers with interpretive statistical algorithms has the potential to develop highly sensitive, highly specific tests to indicate disease presence. While the development of novel in-vitro diagnostic tests is challenging, these tests also have the potential to provide a widely accessible and highly accurate screening modality.

Novel biomarkers (such as those obtained from a measurement of a readily obtained biological sample) that could predict disease presence earlier in the time course of breast cancer are a necessity, given the limitations noted previously with the current breast screening paradigm. One recent example of this is an analytical platform in a growing field of metabolite molecular diagnostics combining nuclear magnetic resonance and two-dimensional gas chromatography-mass spectrometry. A metabolite profiling-based blood test has been shown to identify metabolite signals in serum differentiating patients with breast cancer recurrence from those with no evidence of cancer with a sensitivity of $86 \%$, specificity of $84 \%$, and area under the receiver operating characteristics curve of 0.88 [91]. Over $50 \%$ of patients in that study were accurately predicted to have recurrent breast cancer on average 13 months before the recurrence was clinically apparent, which is two times more sensitive than monitoring serum tumor markers CA27.29 and CA 15-3 currently in use, and which opens a window of opportunity of second line therapy at a much earlier, possibly more treatable stage, than is possible with standard practice [91]. This emphasizes the point that clinically relevant and useful biomarkers must be quantifiable and correlate well with the clinical question intended to be answered. Additionally, as highlighted above, clinically useful biomarkers should be relatively inexpensive, easily exportable throughout the community, and non-invasive so that they can be measured serially over time. 
Improving the quality of risk assessment and screening for breast cancer will likely require an armamentarium of tools and technologies used in an algorithmic, staged approach. In all likelihood a combination of algorithms and biomarkers for first stage risk identification and screening will be required to optimize estimation of risk and detection of disease, which would then support referral into a combination of conventional imaging modalities supported by novel testing platforms such as CTCs.

\section{SUMMARY AND CONSENSUS RECOMMENDATIONS FOR ADVANCING BREAST CANCER RISK IDENTIFICATION AND SCREENING IN ETHNICALLY DIVERSE YOUNGER WOMEN}

Given that more effective treatment strategies have been developed for breast cancer in younger women, safe and effective screening could favorably impact disease-related survival in younger women if it were conducted at shorter intervals than in older women. The following factors were considered important in ensuring continued progress in reducing the burden of breast cancer among young women.

- Development of more robust genetic predictors of disease;

- Development of computational approaches directed toward individual clusters of risk factors and modulatory genes;

- Development of methods by which epigenetic cumulative risk expression can be identified;

- Development of inexpensive technologies by which CTCs can be identified, isolated and quantified in individuals;

- Development of diagnostic platforms of markers of early breast cancer and pre-malignant lesions;

- Designing and fostering clinical trials in young ethnically diverse female populations (such as the U.S. military) with long term follow-up and assessment that can define the level of evidence for and promote the improvement in the above factors and variables.

\section{ABBREVIATIONS}

AAFP: American Association of Family Practitioners; ACOG: American College of Obstetrics and Gynecology; ACS: American Cancer Society; AMA: American Medical Association; BBN: Bayesian Belief Network; BIRADS: breast imaging reporting and data system; BRCA1: Breast cancer 1human tumor suppressor gene; BRCA2: breast cancer 2 human tumor suppressor gene; BSE: breast self examination; CBE: clinical breast examination; CTCs: circulating tumor cells; DTCs: disseminated tumor cells; LCIS: Lobular carcinoma in situ; NCI: National Cancer Institute; NCCN: National Comprehensive Cancer Network; SEER: Surveillance Epidemiology and End Results; TATRC: Telemedicine and Advanced Technology Research Center; USA: U.S. Army; USPSTF: United States Preventive Services Task Force; WHO: World Health Organization

\section{ACKNOWLEDGEMENT}

The authors wish to acknowledge Tiffany Felix for her invaluable assistance supported in part by the Henry M. Jackson Foundation for the Advancement of Military Medicine. We are grateful to the members and staff of the Telemedicine and Advanced Technology Research Center and the Henry M. Jackson Foundation for the Advancement of Military Medicine for their consistent support of this collaborative research effort.

The views expressed in this presentation are those of the authors and do not reflect the official policy of the Department of the Army, the Department of Defense, or the United States Government. Our team includes military service members and employees of the US Government. This work was prepared as part of their official duties.

\section{CONFLICT OF INTEREST}

The authors have declared that no conflict of interest exists.

\section{REFERENCES}

1. Kopans, Daniel B. Breast imaging. Hagerstwon, MD: Lippincott Williams \& Wilkins. 2007

2. [Internet] National Cancer Institute, DCCPS, Surveillance Research Program, Cancer Statistics Branch. Surveillance, Epidemiology, and End Results (SEER) Program; SEER*Stat Database: Incidence - SEER 17 Regs Public-Use, Nov 2005 Sub (1973-2003 varying), released April 2006. www.seer.cancer.gov

3. Department of Epidemiology and Surveillance Research. Breast Cancer Facts and Figures 2009-2010. Atlanta, GA: American Cancer Society. 2010.

4. Kerlikowske K, Grady D Barclay J Sickles EA Ernster V. Positive predictive value of screening mammography by age and family history of breast cancer. JAMA 1993; 270: 2444-50.

5. NCI. Fact Book. US: National Cancer Institute. 2004.

6. Kopans DB. Breast Imaging. Philadelphia: Lippencott-Raven. 1998.

7. Peer PG, Verbeek AL, Mravunac M, Hendriks JH, Holland R. Prognosis of younger and older patients with early breast cancer. Br J Cancer 1996; 73:382-5.

8. Gnerlich JL, Deshpande AD, Jeffe DB, Sweet A, White N, Margenthaler JA. Elevated breast cancer mortality in women younger than age 40 years compared with older women is attributed to poorer survival in early stage disease. J Am Coll Surg $2009 ;$ 208:341-347.

9. Yildirim E, Dalgic T, Berberoglu U. Prognostic significance of young age in breast cancer. J Surg Oncol 2000; 74:267-72. 
10. Xiong Q. Valero V. Kau V. Kau SW. Taylor S. Smith TL. Buzdar AU. Hortobagyi GN. Theriault RL. Female patients with breast carcinoma age 30 years and younger have a poor prognosis: the M.D. Anderson Cancer Center experience. Cancer. 2001; 92(10):2523-8.

11. Feig SA. Mammographic screening of women aged 40-49 years. Benefit, risk, and cost considerations. Cancer 1995; 76: 2097-106.

12. Moskowitz M. Breast cancer: Age-specific growth rates and screening strategies. Radiology 1986; 161:37-41.

13. Pelikan S, Moskowitz M. Effects of lead time, length bias, and false-negative assurance on screening for breast cancer. Cancer 1993; 71:1998-2005.

14. Tabar L, Chen HH, Fagerberg G, et al. Recent results from the Swedish two-county trial: The effects of age, histologic type, and mode of detection on the efficacy of breast cancer screening. Natl Cancer Inst Monogr 1997;:43-47.

15. Tabar L, Fagerberg G, Duffy SW, et al. Update of the Swedish two-county program of mammographic screening for breast cancer. Radiol Clin North Am 1992; 30:187-210.

16. NCI. Surveillance, Epidemiology, and End Results (SEER) Program, SEER 9 Registries, 1973-2006. US: Division of Cancer Control and Population Science, National Cancer Institute. 2009.

17. Salzman P, Kerlikowske K, Phillips K. Cost-effectiveness of extending screening mammography guidelines to include women 40 to 49 years of age. Annals Intern Med. 2003; 127:955-65.

18. Berry DA. Benefits and risks of screening mammography for women in their forties: a statistical appraisal. J Natl Cancer Inst. 1998; 90:1431-39.

19. Larsson LG, Andersson I, Bjurstam N, Fagerberg G, Frisell J, Tabar $L$ et al. Updates overview of the Swedish randomization trials on breast cancer screening with mammography: age group 40-49 randomization. J Natl Cancer Inst Monogr. 1997;: 57-61.

20. Cox B. Variation in the effectiveness of breast cancer screening by year of follow-up. J Natl Cancer Inst Monogr. 1997; :69-72.

21. Glasziou P, Irwig L. The quality and interpretation of mammographic screening trials for women ages 40-49. J Natl Cancer Inst Monogr. 1997; :73-77.

22. Hendrick RE, Smith RA, Rutledge JH 3rd, Smart CR. Benefit of screening mammography in women aged 40-49: a new meta-analysis of randomized controlled trials. J Natl Cancer Inst Monogr. 1997; :87-92.

23. Kerlikowske K. Efficacy of screening mammography among women aged 40 to 49 and 50 to 69 years: comparison of relative and absolute benefit. J Natl Cancer Inst Monogr. 1997; :79-86.

24. Kerlikowske K, Grady D, Ernster V. Benefit if mammography screening in women ages 40-49 years: current evidence from randomized controlled trials. Cancer 1995; 76:1679-81.

25. Humphrey LL, Helfand M, Chan BKS, Woolf SH. Breast cancer screening: A summary of the evidence for the US Preventive Task Force. Ann Intern Med. 2002; 137:347-60.

26. Sackett DL, Rosenberg WM, Gray JA, et al. Evidence based medicine: What it is and what it isn't it. BMJ 1996; 312 (7023): 71-2.

27. Schuster MA, McGlynn EA, Brook RH. How good is the quality of health care in the United States? Milbank Q. 1998; 76(4):517-63.

28. Coates RJ, Uhler RJ, Brogan DJ, Gammon MD, Malone KE, Swanson CA, Flagg EW, Brinton LA. Patterns and predictors of the breast cancer detection methods in women under 45 years of age (United States). Cancer Causes and Control 2001; 12:431-442.

29. Pharoah PD, Lipscombe JM, Redman KL, Day NE, Easton DF, Ponder BA. Familial predisposition to breast cancer in a British population. European Journal of Cancer 2000; 36:773-779.
30. Collaborative Group on Hormonal Factors in Breast Cancer. Familial breast cancer: Collaborative reanalysis of individual data from 52 epidemiological studies including 58,209 women with breast cancer and 101,986 women without disease. The Lancet 2001; 358:1389-1399.

31. Schwab M, Claas A, Savelyeva L. BRCA2: A genetic risk factor for breast cancer. Cancer Letters 2002; 175:1-8.

32. Feig SA, D'Orsi CJ, Hendrick RE, Jackson VP, Kopans DB, Monsees B, Sickles EA, Stelling CB, Zinninger M, Wilcox-Buchalla P. American College of Radiology guidelines for breast cancer screening. American Journal of Roentgenology 1998; 71:29-33.

33. Destouet JM, Sherman ML. The medical audit: How we do it. In: Bassett LW, Jackson VP, Jahan R, Fu YS, Gold RH, eds. Diagnosis of Diseases of the Breast. Philadelphia: WB Saunders. 1997:141-148.

34. Kerlikowske K, Grady D Barclay J Sickles EA Ernster V. Effect of age, breast density and family history on the sensitivity of first screening mammography. Journal of the American Medical Association 1996; 276:33-38.

35. Kerlikowske K, Carney PA, Geller B, Mandelson MT, Teplin SH, Malvin K, Ernster V, Urban N, Cutter G, Rosenberg R, Ballard-Barbash R. Performance of screening mammography among women with and without a first-degree relative with breast cancer. Annals of Internal Medicine 2000; 133:856-863.

36. Bobo JK, Lee NC, Thames SF. Findings from 752081 clinical breast examinations reported to a national screening program from 1995 through 1998. Journal of the National Cancer Institute 2000; 92:971-976.

37. Nelson HD, Tyne K, Naik A, Bougatsos C, Chan B, Nygren P, Humphrey L. Screening for Breast Cancer: Systematic Evidence Review Update for the US Preventive Services Task Force [Internet]. Rockville (MD): Agency for Healthcare Research and Quality (US). 2009.

38. Kriege M, Brekelmans CT, Boetes C, Besnard PE, Zonderland HM, Obdeijn M, Manoliu RA, Kok T, Peterse $H$, Tilanus-Linthorst MM, Muller SH, Meijer S, Oosterwijk JC, Beex LV, Tollenaar RA, de Koning HJ, Rutgers EJ, Klijn JG, Magnetic Resonance Imaging Screening Study Group. Efficacy of MRI and mammography for breast-cancer screening in women with a familial or genetic predisposition. New England Journal of Medicine 2004; 351:427-437.

39. Kopans DB. Clinical breast examination for detecting breast cancer. Journal of the American Medical Association 2000; 283:1688.

40. Pisani P, Parkin DM, Ngelangel C, Esteban D, Gibson L, Munson M, Reyes MG, Laudico A. Outcome of screening by clinical examination of the breast in a trial in the Philippines. Int J Cancer. 2006; 118(1):149-154.

41. Boulos S, Gadallah M, Neguib S, Essam E, Youssef A, Costa A, Mittra I, Miller AB. Breast screening in the emerging world: high prevalence of breast cancer in Cairo. Breast 2005; 14(5):340-346.

42. [Internet] National Cancer Institute. Cancer control research. http:/ / cancercontrol.cancer.gov/grants/abstract.asp?applid=6 965060

43. Thomas DB, Gao DL, Ray RM, et al. Randomized trial of breast self-examination in Shanghai: final results. J Natl Cancer Inst. 2002; 94(19):1445-1457.

44. Semiglazov VF, Manikhas AG, Moiseenko VM, et al. Rezul'taty prospektivnogo randomizirovannogo isledovaniia [Rossiia (Sankt-Peterburg)/VOZ] znacheniia samoobsledovaniia v rannem vyiavlenii raka molochnoi zhelezy. [Results of a prospective randomized investigation [Russia (St.Petersburg)/WHO] to evaluate the significance of self-examination for the early detection of breast cancer]. Vopr Onkol.Voprosy.onkologii. 2003; 49:434-441. 
45. Baxter N, Canadian Task Force on Preventive Health Care. Preventive health care 2001 update: should women be routinely taught breast self-examination to screen for breast cancer? CMAJ. 2001; 164(13):1837-1846.

46. Hackshaw AK, Paul EA. Breast examination and death from breast cancer: a meta-analysis. $\mathrm{Br}$ J Cancer. 2003; 88(7):1047-1053.

47. Kosters JP, Gotzsche PC. Regular self-examination or clinical examination for early detection of breast Cancer. Cochrane Database Syst Rev. 2003;:CD003373.

48. Fenton JJ, Barton MB, Geiger AM, et al. Screening clinical breast examination: how often does it miss lethal breast cancer? J Natl Cancer Inst. 2005;:67-71.

49. Tu SP, Reisch LM, Taplin SH, et al. Breast self-examination: self-reported frequency, quality, and associated outcomes. J Cancer Educ. 2006;21(3):175-181.

50. Smith RA. Breast Cancer Screening Among Women Younger Than Age 50: A Current Assessment of the Issues. Cancer 2000;50:312-336.

51. Chlebowski RT, Hendrix SL, Langer RD, et al. Influence of estrogen plus progestin on breast cancer and mammography in healthy postmenopausal women: the Women's Health Initiative Randomized Trial. Journal of the American Medical Association 2003; 289(24):3243-3253.

52. Boughey JC, Hartmann LC, Degnim AC, Vierkant RA, Reynolds CA, Frost MH, Pankratz VS. Evaluation of the Tyrer-Cuzick (International Breast Cancer Intervention Study) Model for Breast Cancer Risk Prediction in Women with Atypical Hyperplasia. JCO 2010; :3591-3596.

53. MacKarem $G$. The effectiveness of the Gail model in estimating risk for development of breast cancer in women under 40 years of age. Breast Journal. 2001; 7(1):34-9.

54. Fisher B, Costaninno JP, Wickerham DL, et al. Tamoxifen for prevention of breast cancer: Report of the National Surgical Adjuvant Breast and Bowel Project P-1 Study. JNCI 1998; 90 (18):1371-88.

55. Grann VR, Sundararajan V, Jacobson JS, et al. Decision analysis of tamoxifen for the prevention of invasive breast cancer. Cancer J Sci Am 2000; 6:169-178.

56. Hershman D, Sundararajan V, Jacobson JS, et al. Outcomes of tamoxifen chemoprevention for breast cancer in very high-risk women: A cost-effectiveness analysis. J Clin Oncol 2001; 20:9-16.

57. Winchester DP, Osteen RT, Menck HR. The National Cancer Data Base report on breast carcinoma characteristics and outcome in relation to age. Cancer 1996; 78:1838-1843.

58. Smith RA, Saslow D, Sawyer KA, et al. American Cancer Society guidelines for breast cancer screening: update 2003. CA Cancer J Clin 2003; 53(3): 141-69.

59. Joy JE, Penhoet EE, and Petitti DB. Saving Women's Lives: Strategies for Improving Breast Cancer Detection and Diagnosis; Institute of Medicine and National Research Council of the National Academies. Washington DC: National Academy Press. 2004

60. Carney PA, Miglioretti DL, Yankaskas BC, et al. Individual and combined effects of age, breast density, and hormone replacement therapy use on the accuracy of screening mammography. Ann.Intern.Med 2003; 138(3): 168-175.

61. Kroenke CH, Rosner B, Chen WY, Kawachi I, Colditz GA, Holmes MD. Functional impact of breast cancer by age at diagnosis. J Clin Oncol 2004; 22(10): 1849-56.

62. Warner E, Plewes DB, Hill KA, et al. Surveillance of BRCA1 and BRCA2 mutation carriers with magnetic resonance imaging, ultrasound, mammography, and clinical breast exam. JAMA 2004; 292:1317-1325.

63. Wacholder S, Hartge P, Prentice R, Garcia-Closas M, Feigelson HS, Diver WR, Thun MJ, Cox DG, Hankinson SE, Kraft P, Ros- ner B, Berg CD, Brinton LA, Lissowska J, Sherman ME, Chlebowski R, Kooperberg C, Jackson RD, Buckman DW, Hui P, Pfeiffer R, Jacobs KB, Thomas GD, Hoover RN, Gail MH, Chanock SJ, Hunter DJ. Performance of common genetic variants in breast-cancer risk identification and screening. NEJM 2010; 362(11): 986-93.

64. Moss SM, Cuckle H, Evans A, Johns L, Waller M, Bobrow L; Trial Management Group. Effect of mammographic screening from age 40 years on breast cancer mortality at 10 years' follow-up: a randomised controlled trial. Lancet. 2006; 368:2053-60.

65. Stojadinovic A, Eberhardt C, Henry L, Eberhardt J, Peoples GE, Nissan A, Shriver CD. Development of a Bayesian Classifier for Breast Cancer Risk Stratification: A Feasibility Study. ePlasty Open Access Journal 2010; 10:203-216.

66. Schlimok G, Funke I, Holzmann B, et al. Micrometastatic cancer cells in bone marrow: in vitro detection with anti-cytokeratin and in vivo labeling with anti-17-1A monoclonal antibodies. Proc Natl Acad Sci U S A 1987; 84(23):8672-6.

67. Nagrath, S. Isolation of rare circulating tumour cells in cancer patients by microchip technology. Nature 2007; 450(7173):1235-9.

68. Zheng, S. Membrane microfilter device for selective capture, electrolysis and genomic analysis of human circulating tumor cells. J. Chromatogr. 2007; 1162(2):154-61.

69. Yang, L. Optimization of an enrichment process for circulating tumor cells from the blood of head and neck cancer patients through depletion of normal cells. Biotechnol. Bioeng. 2009; 102(2):521-34.

70. Cote RJ, Rosen PP, Lesser ML, et al. Prediction of early relapse in patients with operable breast cancer by detection of occult bone marrow micrometastases. J Clin Oncol 1991; 9:1749-56.

71. Muller P, Weckermann D, Riethmuller G, et al. Detection of genetic alterations in micrometastatic cells in bone marrow of cancer patients by fluorescence in situ hybridization. Cancer Genet Cytogenet 1996; 88:8-16.

72. Klein CA, Schmidt-Kittler O, Schardt JA, et al. Comparative genomic hybridization, loss of heterozygosity, and DNA sequence analysis of single cells. Proc Natl Acad Sci U S A 1999; 96:4494-9.

73. Riethmuller G, Johnson JP. Monoclonal antibodies in the detection and therapy of micrometastatic epithelial cancers. Curr Opin Immunol 1992; 4(5):647-55.

74. Beitsch PD, Clifford E. Detection of Carcinoma Cells in the Blood of Breast Cancer Patients. Am J Surg 2000; 180:446-9.

75. Klein CA, Blankenstein TJF, Schmidt-Kittler O, et al. Genetic heterogeneity of single disseminated tumour cells in minimal residual cancer. The Lancet 2002; 360:683-9.

76. Schmidt-Kittler O, Ragg T, Daskalakis A, et al. From latent disseminated cells to over metastasis: Genetic analysis of systemic breast cancer progression. Proc Natl Acad Sci U S A 2003; 100(13):7737-42.

77. Yang J, Mani SA, Donaher JL, et al. Twist, a Master Regulator of Morphogenesis, Plays an Essential Role in Tumor Metastasis. Cell 2004; 117(7):927-39.

78. Chin K, de Solorzano CO, Knowles D, et al. In Situ analyses of genome instability in breast cancer. Nat Genet 2004; 36(9):984-8.

79. Braun S, Vogl FD, Naume B, et al. A Pooled Analysis of Bone Marrow Micrometastasis in Breast Cancer. N Engl J Med 2005; 353(8):793-802.

80. Schardt JA, Meyer M, Hartmann $\mathrm{CH}$, et al. Genomic analysis of single cytokeratin-positive cells from bone marrow reveals early mutational events in breast cancer. Cancer Cell 2005; 8(3):227-39. 
81. Olivier M, Langerod A, Carrieri P, et al. The Clinical Value of Somatic TP53 Gene Mutations in 1,794 Patients with Breast Cancer. Clin Cancer Res 2006; 12(4):1157-67.

82. Klein CA, Holzel D. Systemic Cancer Progression and Tumor Dormancy: Mathematical Models Meet Single Cell Genomics. Cell Cycle 2006; 5(16):1788-98.

83. Husemann Y, Geigl JB, Schubert F, et al. Systemic Spread is an Early Step in Breast Cancer. Cancer Cell 2008; 13(1):58-68.

84. Klein CA. The direct molecular analysis of metastatic precursor cells in breast cancer: A chance for a better understanding of metastasis and for personalized medicine. Eur J Canc 2008; 44:2721-5.

85. Engel J, Eckel R, Kerr J, et al. The process of metastasisation for breast cancer. Eur J Cancer 2003; 39:1794-1806.

86. Brandt B, Roetger A, Heidl S, et al. Isolation of Blood-Borne Epithelium-Derived c-erbB-2 Oncoprotein-Positive Clustered Cells from the Peripheral Blood of Breast Cancer Patients. Int J Cancer 1998; 76:824-8.

87. Frazier TG, Rose D, Flynn M, et al. Circulating epithelial cells are elevated in women with a suspicious breast mass [abstract]. San Antonio, TX: 25th Annual San Antonio Breast Cancer Symposium. 2002.

88. Meng S, Tripathy D, Frenkel EP, et al. Circulating Tumor Cells in Patients with Breast Cancer Dormancy. Clin Cancer Res 2004; 10:8152-62.

89. Cristofanilli M, Budd GT, Ellis MJ, et al. Circulating Tumor Cells, Disease Progression, and Survival in Metastatic Breast Cancer. N Engl J Med 2004; 351:781-91.

90. Biomarkers Definitions Working Group. Biomarkers and surrogate endpoints: preferred definitions and conceptual framework. Clin Pharmacol Ther 2001;69: 89-95.

91. Asiago VM, Alvarado LZ, Shanaiah N, Gowda GA, Owusu-Sarfo K, Ballas RA, Raftery D. Early detection of recurrent breast cancer using metabolite profiling. Cancer Res. 2010; 70(21):8309-18 